\title{
ULTRASTRUCTURE AND ENDOCRINOLOGICAL CORRELATES OF AN EARLY IMPLANTATION SITE IN THE RHESUS MONKEY
}

\author{
S. REINIUS, * G. R. FRITZ AND E. KNOBIL \\ Department of Anatomy, Uppsala, Sroeden, and \\ Department of Physiology, University of Pittsburgh School of Medicine, \\ Pittsburgh, Pennsylvania, U.S.A.
}

(Received 4th September 1972)

\begin{abstract}
Summary. An implanting blastocyst of a rhesus monkey killed on the 9th day after ovulation has been observed, using light- and electronmicroscopy. The time of pregnancy was determined from the patterns of the circulating ovarian hormones and of $\mathrm{LH}$ from the beginning of the menstrual cycle to the day of autopsy. At this stage of implantation, the penetration of the epithelium by trophoblast cells had begun at a few sites along the area of attachment but the basement membrane was not reached. These events preceded measurable increments in circulating chronic gonadotrophin and the 'rescue' of the corpus luteum.
\end{abstract}

Ultrastructural studies of the implantation process are lacking in Primates. Since the time of ovulation in the rhesus monkey can now be accurately determined (Johansson, Neill \& Knobil, 1968) and morphological preparatory techniques yield sufficiently good preservation (Reinius, 1967), a study of implantation in the rhesus monkey was initiated.

Three mature female rhesus monkeys with histories of regular menstrual cycles of normal duration were studied. Daily blood samples were obtained by femoral venepuncture from the 1st day of the cycle to the time of autopsy 9 to 10 days after the day of ovulation as estimated by the fall in circulating progestins. The animals were mated with fertile males at the time of ovulation. Blood samples were analysed for progesterone (Neill, Johansson, Datta \& Knobil, 1967), 'progestin' (Johansson et al., 1968), LH (Monroe, Peckham, Neill \& Knobil, 1970), chorionic gonadotrophin (Atkinson, Hotchkiss, Frizt, Surve \& Knobil, 1971) and oestrogen (Hotchkiss, Atkinson \& Knobil, 1971).

The tissues were fixed at autopsy by abdominal perfusion with a solution of $2.5 \%$ glutaraldehyde in Sorenson buffer. The uterus, oviducts and ovaries were dissected free. In all three monkeys, a normal corpus luteum was observed. The body of the uterus was then opened by a paramedian incision under glutaraldehyde solution and the walls were inspected for blastocysts. None were found in two of the animals. The uterus of the third animal killed on the 9th day after

* Present address: Department of Obstetrics and Gynecology, University Hospital, S750 14 Uppsala 14, Sweden. 
ovulation contained a blastocyst attached to the central area of the posterior wall, which was viewed through a stereomicroscope. A specimen measuring $8 \times 7 \times 3 \mathrm{~mm}$, consisting of the posterior wall with the blastocyst, the opposing wall and an adjoining lateral wall, was removed for embedding in Epon. Serial sectioning for light microscopy was made until the blastocyst was reached. Then the specimen was trimmed for electron microscopy to an area of about $0.8 \times$ $0.2 \mathrm{~mm}$. Thin serial sections were picked up on one-hold grids.

The results showed the epithelial surfaces to be lying about $400 \mu \mathrm{m}$ apart. A typical epithelial reaction was observed to a distance of approximately $2 \mathrm{~mm}$ from the implantation site- the epithelial plaque - on both the surface with the attached blastocyst (Pl. 1, Fig. 1) and the opposing surface. The blastocyst measured about $0.2 \times 0.6 \mathrm{~mm}$ and was somewhat flattened, probably as a consequence of fixation and/or preparation. The abembryonic pole seemed to be unattached to the opposing wall. The area of attachment measured about $0.3 \times 0.3 \mathrm{~mm}$.

Under the light microscope, only one layer of trophoblast cells was observed (Pl. 1, Fig. 1). The cells were lying in contact with the epithelial surface. Two different types of epithelial cells were distinguished at the implantation site. The cells in contact with the trophoblast cells had a dark-stained cytoplasm and formed two to three layers, which often appeared to contain many nuclei, as judged from examining serial sections. Basally, large lightly stained cells with one nucleus were visible. The basement membrane had not been reached by trophoblast cells. Large capillaries were often found below the thinner parts of the epithelium.

Under the electron microscope, the trophoblast cells and the epithelial surface showed different interrelationships. Along the main contact surface, many long and broad microvilli from the trophoblast cells extended into the epithelial surface (Pl. 1, Fig. 2). This surface also had many long microvilli, which interlaced with those of the trophoblast, making the contact rather complex. In other areas, one or two trophoblast cells had a smooth surface which was in contact with a similarly smooth epithelial surface. Along the contact areas, quite a few desmosome-like structures were found (Pl. 1, Fig. 2). The basal light cells were not easily distinguished from the trophoblast cells, but were probably maternal, since they are seen in epithelium outside the implantation area. Parts of epithelial cells were seen within the trophoblast cells. No trophoblastic syncytium could be observed.

At a few sites, the trophoblast cells had formed two or three layers that had penetrated the superficial layer of epthelial cells and made contact with the basal cells (Pl. 2, Fig. 3). At these sites, whole degenerated cells with their nuclei were seen between trophoblast cells, but fragments of cells were also seen, both in trophoblast cells and basal epithelial cells. These basal epithelial cells could be mistaken for trophoblast cells that had penetrated to the basal membrane of the epithelium. Further examinations of serial sections of the whole implantation area are required to elucidate the nature and significance of these cells.

The age of the implantation seems not to be more than 1 day, according to the description of Heuser \& Streeter (1941).

In this animal, ovulation occurred on Day 12 of the menstrual cycle as 
PLATE 1

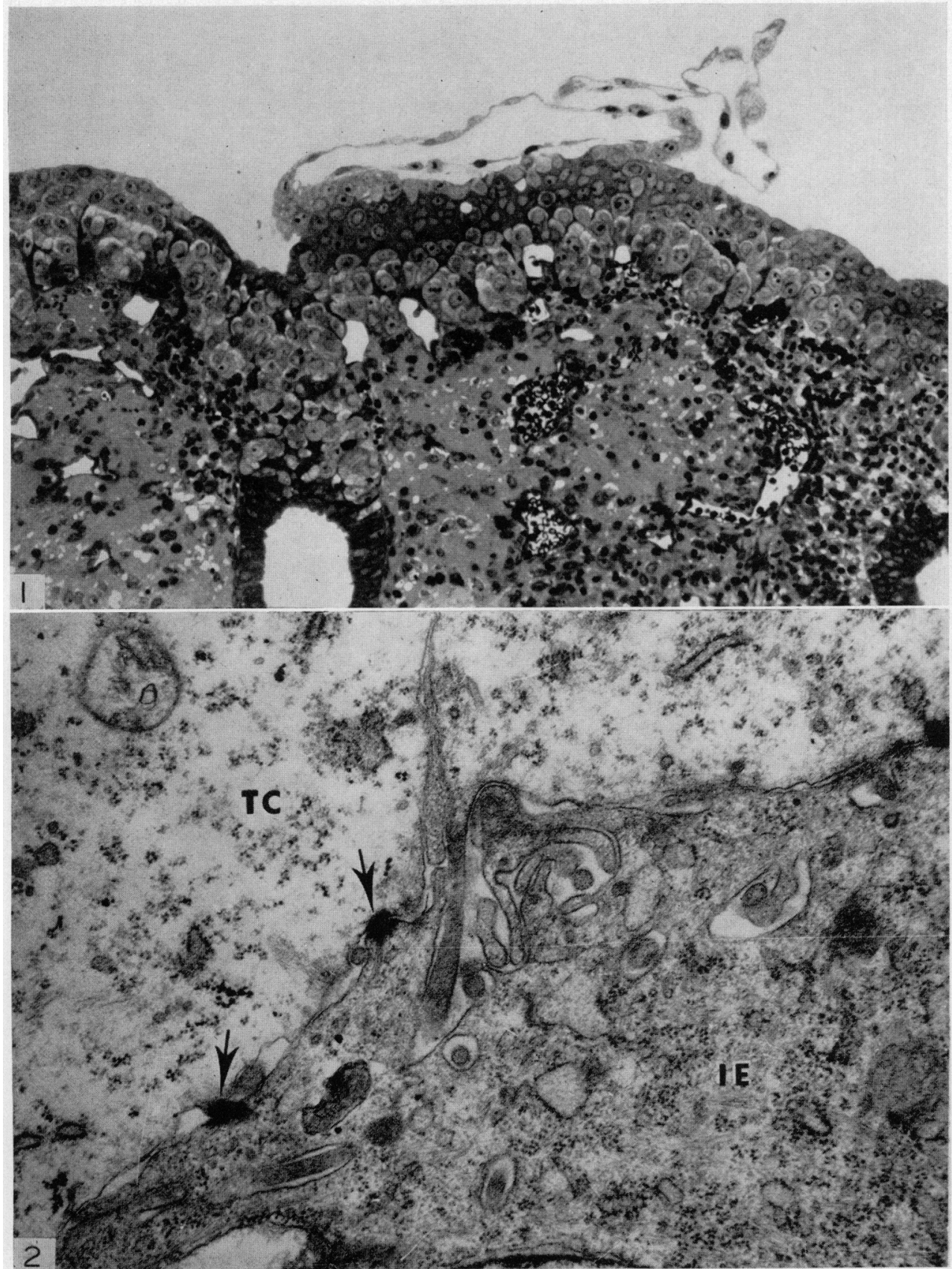

Fig. 1. The blastocyst is secn attached to the epithelium. $\times 170$.

Fis. 2. Trophoblast-epithelial contact. Long, broad microvilli from the trophoblast cell TC penetrate into the darker stained epithelial coll (IE). Desmosonue-like structures are seen arroust. $\times 30,000$.

(Facing (1. 172) 


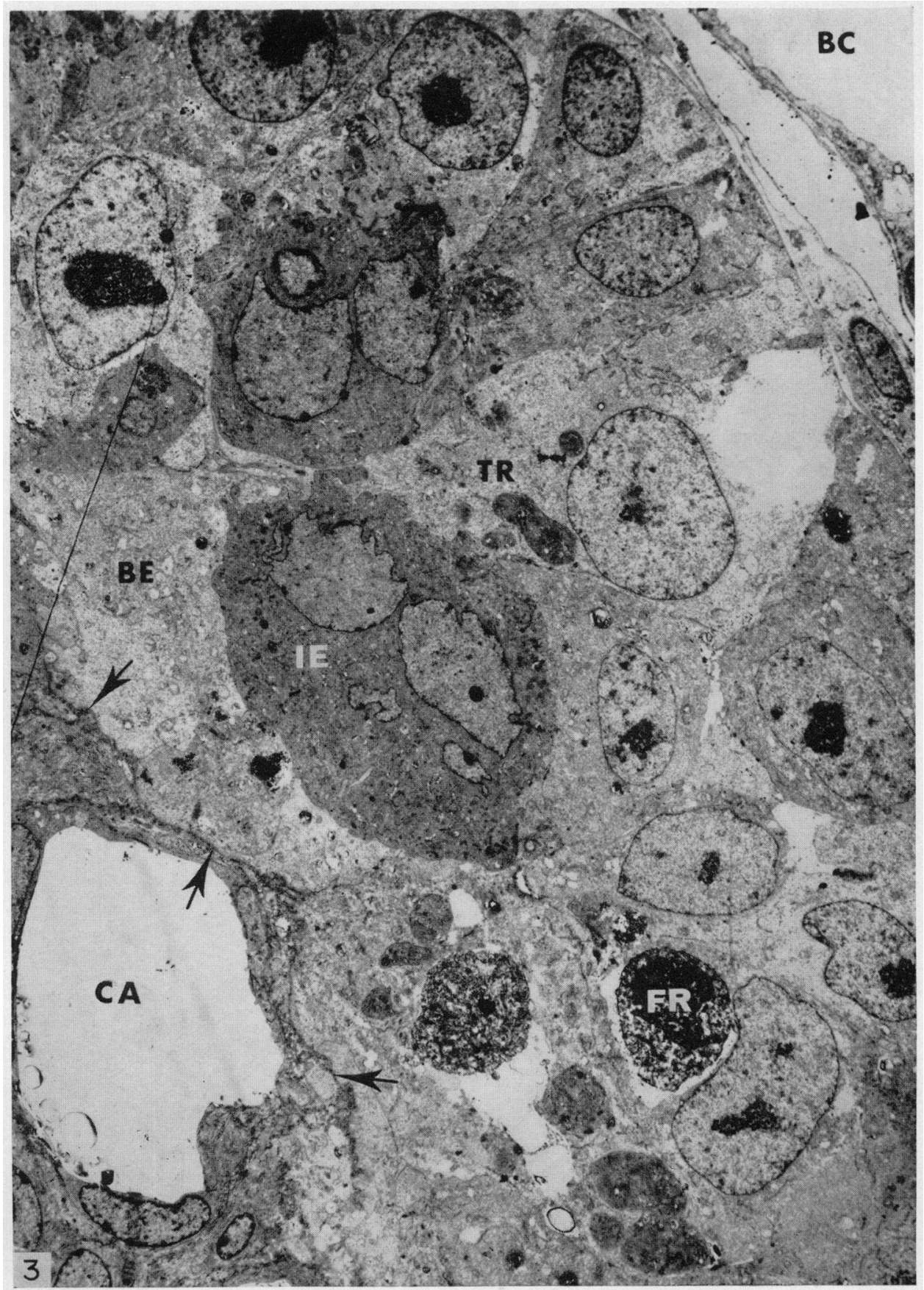

Fis; 3. Trophoblast cell ('RR, to the right, and light-stained epithelial cells (BE) on the basement membranc (amows) surround areas of dark-stained rpithelial cells (IE). Both cells also contain fragments of epithelial cells (FR). BC: Blastocyst cavity: (AA, maternal capillaty: $\times 2000$. 
judged from the fall in plasma progestin concentration on that day (Johansson et al., 1968) and the LH peak on the preceding one (Monroe, Atkinson \& Knobil, 1970). It is of interest that at the stage of implantation described above (9 days after the day of ovulation or Day 10 of pregnancy), the circulating levels of the ovarian hormones and of LH were indistinguishable from those observed in the other two animals in which no blastocysts were found or in non-mated monkeys at equivalent stages of the menstrual cycle. Chorionic gonadotrophin had not yet appeared in measurable concentrations. The 'rescue' of the corpus luteum, ascribed to the production of chorionic gonadotrophin in early pregnancy (Neill, Johansson \& Knobil, 1969; Neill \& Knobil, 1972; Atkinson et al., 1971) must, therefore, occur somewhat later than the stage of pregnancy herein described.

This work was supported by Grants HD 03969 and RR 00298 from the NIH, USPHS and by a grant from the Ford Foundation to E. Knobil. Acknowledgements are directed to L.K.B., for much aid in the sectioning of the material.

\section{REFERENGES}

Atrinson, L. E., Hotchkiss, J., Fritz, G. R., Surve, A. H. \& KnobiL, E. (1971) Girculating levels or luteinizing hormone (LH), chorionic gonadotrophin (CG), estrogens $(E)$, and progesterone $(P)$ during pregnancy in the rhesus monkey. Biol. Reprod. 5, 95.

Heuser, G. H. \& Streeter, G. L. (1941) Development of the macaque embryo. Contr. Embryol. 29, no. $181,17$.

Hotchkiss, J., Atkinson, L. E. \& KNoBiL, E. (1971) Time course of serum estrogen and luteinizing hormone (LH) concentrations during the menstrual cycle of the rhesus monkey. Endocrinology, 89, 177.

Johansson, E. D. B., Neill, J. D. \& KnobiL, E. (1968) Periovulatory progesterone concentration in the peripheral plasma of the rhesus monkey with a methodologic note on the detection of ovulation. Endocrinology, 82, 143.

Monroe, S. E., Atkinson, L. E. \& Knobil, E. (1970) Patterns of circulating luteinizing hormone and their relation to plasma progesterone levels during the menstrual cycle of the rhesus monkey. Endocrinology, 87, 453.

Monroe, S. E., Peckham, W. D., Neill, J. D. \& Knobir, E. (1970) A radioimmunoassay for rhesus monkey luteinizing hormone ( $\mathrm{RhLH})$. Endocrinology, 86, 1012.

NeILL, J. D., Johansson, E. D. B. \& KNoBIL, E. (1969) Patterns of circulating progesterone concentrations during the fertile menstrual cycle and the remainder of gestation in the rhesus monkey. Endocrinology, 84, 45.

Neill, J. D., Johansson, E. D. B., Datta, J. K. \& Knobil, E. (1967) The relationship between the plasma levels of luteinizing hormone and progesterone during the normal menstrual cycle. $\mathcal{F}$. clin. Endocr. Metab. 27, 1167.

Nerll, J. D. \& KNoBIL, E. (1972) On the nature of the initial luteotropic stimulus of pregnancy in the rhesus monkey. Endocrinology, 90, 34.

Reinus, S. (1967) Ultrastructure of blastocyst attachment in the mouse. Z. Zellforsch. mikrosk. Anat. 77, 257: 